\title{
ETHNIC CLASSIFICATION AMONG SECONDARY SCHOOL TEACHERS AND STUDENTS IN HUNGARY
}

\author{
DOROTTYA KISFALUSI
}

\begin{abstract}
This study focuses on ethnic classification among secondary school teachers and Roma and non-Roma Hungarian secondary school students. It is expected that students living in better socio-economic circumstances are less likely to be classified as Roma by their classmates and teachers than students with a poorer socio-economic background. It is also assumed that students with more Roma friends are more likely to be classified as Roma than students with fewer Roma friends. First-wave data from a Hungarian panel study were analyzed. To test the hypotheses, cross-sectional logistic and fractional regression analyses were conducted for 17 classes $(N=559)$. Results suggest that, consistent with the hypotheses, students from low-status families and students with more incoming friendship nominations from Roma classmates are more likely to be classified as Roma by their teachers and peers than high-status students and students with fewer Roma friends, even after controlling for the students' ethnic self-identification.
\end{abstract}

KEYWORDS: adolescents, ethnic classification, ethnic perceptions, Roma, social networks

\footnotetext{
1 Dorottya Kisfalusi is assistant research fellow at the Institute for Sociology, Centre for Social Sciences, Hungarian Academy of Sciences; researcher at MTA TK 'Lendület' Research Center for Educational and Network Studies (RECENS); assistant professor at the Institute of Sociology and Social Policy, Corvinus University of Budapest, e-mail: kisfalusi.dorottya@tk.mta.hu.

The author would like to thank Tamás Bartus, Béla Janky, and Károly Takács for their helpful comments and suggestions. This work was supported by the Hungarian Scientific Research Fund under OTKA K81336 'Wired into Each Other: Network Dynamics of Adolescents in the Light of Status Competition, School Performance, Exclusion and Integration'; and the Hungarian Academy of Sciences under 'Competition and Negative Networks' Lendület program.
} 


\section{INTRODUCTION}

Ethnic classification may have serious consequences for minority members' economic and social circumstances. People classified as members of a stigmatized minority often face social and economic exclusion in a lot of areas of life. Roma in Hungary, for instance, face strong discrimination and prejudice. This phenomenon results in residential as well as school segregation, since non-Roma Hungarians often leave areas and schools with a significant Roma population (Kertesi and Kézdi, 2013; Ladányi and Szelényi, 2006). Roma students, and furthermore students of other visibly different minority groups in Europe, are more likely to get lower grades from school teachers than their majority peers (Messing et al., 2010; Szalai, 2014). People perceived as Roma are also less likely to be hired by employers than non-Roma applicants (Sik and Simonovits, 2008). These mechanisms, together with other economic factors, contribute to the existence of a gap between the Roma and non-Roma population with regard to employment rate, average level of education, and exposure to poverty (FRA, 2017; Kemény and Janky, 2006; Kertesi and Kézdi, 2011).

Therefore, it is of primary interest to analyze the mechanisms that govern ethnic classification. People's perceptions of each other's ethnicity does not only depend on self-declared ethnicity, but on several other factors such as physical characteristics, language use, family name, lifestyle, residence, social position, and social status (Csepeli and Simon, 2004; Telles, 2002; Telles and Paschel, 2014). An individual's ethnic classification (the way others categorize someone as a member of an ethnic group) may thus be different from their ethnic identification (the way individuals identify themselves ethnically (Boda, 2018; Boda and Néray, 2015; Csepeli and Simon, 2004; Messing, 2014; Telles and Lim, 1998). Moreover, ethnic classification and identification may influence each other, and both of them can change in context and time (Harper, 2016; Ladányi and Szelényi, 2006; Saperstein and Penner, 2012; Simonovits and Kézdi, 2014).

This study examines ethnic classification in a special context: in secondary school classrooms. First-wave data from a Hungarian panel study conducted among Roma and non-Roma students were analyzed. I investigated whether students' socio-economic status and friendship ties are associated with how their ethnicity is perceived by their classmates and teachers. The main novelty of the study is that, besides ethnic self-identification and classification by teachers, dyadic ethnic perceptions of students were also measured: every student was asked to classify the ethnicity of their classmates. The dataset therefore provides a unique opportunity to study ethnic classification processes. 


\section{Socio-economic status and ethnic classification}

Different ethnic groups have different opportunities to assert the ethnic identities they want to be associated with (Song, 2001; Waters, 1996). As a result, individuals' self-declared ethnic identification might be different from how they are classified by others (Csepeli and Simon, 2004; Ladányi and Szelényi, 2006; Telles, 2002; Telles and Lim, 1998). In Brazil, a country with especially ambiguous racial boundaries, survey interviewers tended to 'whiten' more highly educated people who self-identified as brown (Telles, 2002), and people with a higher income (Telles and Lim, 1998). In another study, better educated non-white Brazilian parents were more likely to classify their children as white than less well-educated non-white parents (Schwartzman, 2007).

In the United States, people living in poverty and those who had been unemployed or incarcerated were more likely to be classified as black and less likely to be classified as white, regardless of how they were categorized previously (Saperstein and Penner, 2012). Moreover, experiments have demonstrated that being dressed as a low-status person increases the likelihood of being classified as black, whereas being dressed as a high-status person increases the likelihood of being classified as white. In the study, this association became stronger when racially more ambiguous faces were shown (Freeman et al., 2011).

In Hungary, being classified as Roma by others seems to be positively associated with low socio-economic status. Individuals living in poverty are more likely to be classified as Roma than high-status individuals (Csepeli and Simon, 2004). Therefore, Roma people who are more similar to the majority middle class society may avoid being classified as Roma (Ladányi and Szelényi, 2006). Thus, it is hypothesized that students who live in better socio-economic circumstances are less likely to be classified as Roma by their teachers than students living under worse socio-economic conditions (Hypothesis 1a); and that students who live in better socio-economic circumstances are less likely to be classified as Roma by their peers than students living in worse socioeconomic conditions (Hypothesis 1b).

\section{Social networks and ethnic classification}

Identity theory (Burke, 1991) identifies social networks as driving factors of identity change (McFarland and Pals, 2005). Identity theory rests on the assumption that one's identities consist of a collection of role identities that emerge from membership in different groups or roles (Stets and Burke, 2000). Particular 
network contexts influence the salience of various identities constituting the self, and motivate identity change depending on the salience of those identities with regard to the actual context (Stryker and Burke, 2000). Indeed, McFarland and Pals (2005) found that network relations played a crucial role in the identity development of adolescents. Munniksma et al. (2015) suggested that there was a bidirectional relationship between interethnic friendships and host society identification among immigrants.

Social ties, however, not only influence ethnic identification and identity but might have an effect on classification. People with minority friends could be considered members of the minority group and thus more likely to be classified as minorities by others than people without (or with fewer) minority friends. Boda (2015) found that students who were popular among their Roma peers were likely to be perceived as Roma by their classmates. Students with a central position among non-Roma peers were likely to be perceived as non-Roma. It is thus expected that students with more Roma friends in a class are more likely to be classified as Roma by their teachers than students with fewer Roma friends in a class (Hypothesis 2a); and that students with more Roma friends in a class are more likely to be classified as Roma by their peers than students with fewer Roma friends in a class (Hypothesis $2 b$ ).

\section{The education of Roma youth in Hungary}

The Roma constitute the largest ethnic minority group in Hungary. Their proportion is estimated to be between 3 and 6 percent $^{2}$ of the total Hungarian population (Hungarian Central Statistical Office, 2013; Kemény and Janky, 2006), and around 10-12 percent of school-age children (Kemény and Janky, 2006). Different Roma groups have been living in Hungary for centuries, and they have often experienced separation and exclusion by majority society (Kertesi and Kézdi, 2011).

The educational segregation of socially disadvantaged and Roma students is a substantial problem in Hungary. The extent of between-school segregation has been increasing over the past few decades (Kertesi and Kézdi, 2013, 2012). Reasons include the residential segregation of Roma families, segregationist

2 Different estimations exist, depending on the means of classification. Based on the 2011 population census, the proportion of those people self-declaring as Roma is 3.11 percent of the Hungarian population (Hungarian Central Statistical Office, 2013). Kemény and Janky (2006) estimated the proportion of those people who are classified as Roma by the non-Roma community to be 5-6 percent (Kemény and Janky, 2006). 
local educational policies, the system of free school choice ${ }^{3}$, and middle class student mobility (Kertesi and Kézdi, 2013). Schools enrolling high numbers of Roma students often provide lower quality education than schools educating majority middle-class students regarding the quality of school facilities, educational services, and qualifications and motivation of teachers. This phenomenon further increases educational inequalities between social groups.

The average test score of Roma eight graders is approximately one standard deviation below the average of non-Roma eight graders for both reading and mathematical literacy skills based on data from the Hungarian National Assessment of Basic Competences in 2006 (Kertesi and Kézdi, 2011). Roma children are more likely not to continue their studies at all after finishing primary school, or to choose vocational schools which do not lead to entrance to tertiary education in Hungary, and are less likely to choose secondary technical or grammar schools than non-Roma children. Furthermore, the dropout rate of Roma students is considerably higher during their secondary education than that of non-Roma youth (Kertesi and Kézdi, 2009). A recent study showed that Roma students also receive lower grades from teachers than their non-Roma peers, even if they have a relatively good socio-economic position (Messing et al., 2010).

\section{The present study}

The present study focuses on ethnic classification processes among secondary school teachers and Roma and non-Roma secondary school students in Hungary. To test the hypotheses I estimate different types of cross-sectional regression models for 17 secondary school classes. First, logistic regression analysis is applied to investigate how teachers classify their students. Second, fractional regression analysis (Papke and Wooldridge, 1996; Ramalho et al., 2011 ) is conducted to examine the associations between an aggregated measure of the classmates' classifications (indicating the percentage of classmates who classified respondents as Roma), on the one hand, and the social status and social ties of the students, on the other.

3 In Hungary, schools are required to admit all children from their own district, but if they do not reach the maximum capacity they are allowed to enrol students living outside of the district. This educational system allows parents to send their children to any available school, provided there is space for them. 


\section{DATA AND METHOD}

\section{Participants and procedure}

I analyzed the first wave of data ${ }^{4}$ of a four-wave panel study conducted among Roma and non-Roma students in 44 classrooms in seven secondary schools $(\mathrm{N}=1425)$. The main aim of the project was to examine the ethnic segregation of the students' social networks, and the associations between the individuals' characteristics and their actual or perceived position in the hierarchy of the class. Schools with a high proportion of Roma students were overrepresented in the sample. Schools were located in the capital city, in one large town, and in two middle-sized towns in the eastern part of Hungary. The first wave data were gathered in the autumn of 2010, a few weeks after the beginning of the students' first academic year in secondary education.

Before data collection took place students and parents received a consent form and an information letter describing the aim and procedure of the research. Parents were asked to return the consent form if they did not want their child to participate in the study. Students who had been granted parental permission (99.3\%) filled out a self-administered paper questionnaire during regular school lessons, under the supervision of a trained research assistant. Students were assured that their answers would be kept confidential and would be used for research purposes exclusively. They were also allowed to refuse to participate in the study. In order to obtain additional information about students and classes, information was collected from headmasters using questionnaires filled in by trained interviewers.

Those classrooms were selected from the sample where the response rate reached 70 per cent, at least three self-declared Roma students attended the class, and a completed questionnaire with the headmaster was available. Thus, the subsample comprised 17 classes with a mean class size of $33(\mathrm{SD}=3.41)$. Seven classes were vocational school classes, which do not offer the chance to enter tertiary education in Hungary. Eight classes were technical school classes, and two classes were grammar school classes (representing the highest level of secondary education in Hungary). In the first wave, 212 boys (37.9 per cent) and 347 girls (62.1 per cent) attended these classes (mean age $=15.1$ years). More girls than boys participated in the research because a lot of vocational and technical school classes in the sample provided education for professions

\footnotetext{
4 In the second wave, no completed teacher's questionnaires are available for around half of the classes. After the second wave of the research, the number of self-declared Roma students dropped significantly in the sample (due to changes in class composition).
} 
that are more likely to be chosen by female than male students. Table 1 presents descriptive statistics about the 17 classes.

Table 1. Descriptive statistics about the 17 classes

\begin{tabular}{|c|c|c|c|c|c|c|}
\hline $\begin{array}{l}\text { School } \\
\text { type }\end{array}$ & $\begin{array}{c}\text { Type of } \\
\text { settlement }\end{array}$ & $\mathrm{N}$ & $\begin{array}{c}\text { Number of } \\
\text { students self- } \\
\text { declared as Roma } \\
\text { only }\end{array}$ & $\begin{array}{c}\text { Number of } \\
\text { students self- } \\
\text { declared as Roma } \\
\text { and Hungarian }\end{array}$ & $\begin{array}{l}\text { Proportion } \\
\text { of Roma* }\end{array}$ & $\begin{array}{l}\text { Number } \\
\text { of girls }\end{array}$ \\
\hline Technical & Large town & 27 & 6 & 9 & $55.6 \%$ & 23 \\
\hline Technical & Large town & 31 & 12 & 3 & $48.4 \%$ & 22 \\
\hline Technical & Large town & 30 & 8 & 4 & $40.0 \%$ & 16 \\
\hline Technical & Large town & 29 & 5 & 1 & $20.7 \%$ & 18 \\
\hline Vocational & Large town & 35 & 10 & 8 & $51.4 \%$ & 17 \\
\hline Vocational & Large town & 32 & 11 & 8 & $59.4 \%$ & 21 \\
\hline Grammar & $\begin{array}{l}\text { Middle-sized } \\
\text { town } 1\end{array}$ & 34 & 2 & 2 & $11.8 \%$ & 26 \\
\hline Technical & $\begin{array}{l}\text { Middle -sized } \\
\text { town } 1\end{array}$ & 37 & 2 & 6 & $21.6 \%$ & 2 \\
\hline Grammar & $\begin{array}{l}\text { Middle -sized } \\
\text { town } 1\end{array}$ & 36 & 0 & 4 & $11.1 \%$ & 14 \\
\hline Vocational & $\begin{array}{l}\text { Middle -sized } \\
\text { town } 1\end{array}$ & 37 & 15 & 6 & $56.8 \%$ & 32 \\
\hline Technical & $\begin{array}{l}\text { Middle -sized } \\
\text { town } 2\end{array}$ & 38 & 2 & 5 & $18.4 \%$ & 30 \\
\hline Vocational & $\begin{array}{l}\text { Middle -sized } \\
\text { town } 2\end{array}$ & 33 & 4 & 6 & $30.3 \%$ & 26 \\
\hline Vocational & $\begin{array}{l}\text { Middle -sized } \\
\text { town } 2\end{array}$ & 26 & 9 & 4 & $50.0 \%$ & 0 \\
\hline Technical & $\begin{array}{l}\text { Middle -sized } \\
\text { town } 2\end{array}$ & 35 & 3 & 6 & $25.7 \%$ & 18 \\
\hline Vocational & $\begin{array}{l}\text { Middle -sized } \\
\text { town } 2\end{array}$ & 31 & 10 & 10 & $64.5 \%$ & 31 \\
\hline Technical & Capital & 33 & 3 & 2 & $15.2 \%$ & 27 \\
\hline Vocational & Capital & 35 & 3 & 6 & $25.7 \%$ & 24 \\
\hline
\end{tabular}

* The proportion of Roma students was calculated by summing the number of self-reported 'both Roma and Hungarian', and 'Roma' students. 
In the regression analyses, only those students were included who gave valid answers to the questions concerning every dependent and independent variable, or whose answers could be imputed based on other waves $(\mathrm{N}=499$, see details about imputation in the next section).

\section{Measures}

Dependent variable in the logistic regression model: Roma classification by teachers. Headmasters were provided with a list of all the students in their class and were asked to nominate those whom they considered Roma. A dummy variable indicating whether the student was nominated as Roma by the headmaster was used as the dependent variable in the logistic regression analysis.

Dependent variable in the fractional regression model: Roma classification by peers. Students were provided with a list of all classmates and were asked to nominate those whom they considered Roma. By calculating the proportion of classmates who classified a respondent as Roma, a variable was created with scores ranging from 0 to 1 . First, the in-degree for each student was calculated by summing the received nominations from others. Second, the in-degrees were divided by the number of classmates in order to take into account differences in the size of classes. This measure of Roma classification was used as the dependent variable in the fractional regression analysis.

Socio-economic status. Two measurements of students' socio-economic background were included in the analysis: a dummy variable indicated whether students were entitled to a regular child support allowance based on their family background and social circumstances, and a variable measured the mother's highest educational attainment, which was originally classified into seven categories: 1. fewer than eight years of primary school, 2. primary school, 3. vocational school, 4 . secondary technical school, 5. secondary grammar school, 6. college (BA), and 7. university (MA). The values of this variable were recoded into four categories: 1. eight classes of primary school or lower, 2. vocational school, 3. finished secondary education, and 4. finished tertiary education. This variable was included as a set of dummy variables with the primary school as the reference category in the regression models. Missing data about mothers' level of education were imputed using data from the other waves.

Number of Roma friends in the class. Students were provided with a list of all classmates and were asked to select their friends. For every student, both the incoming and outgoing nominations (in- and out-degrees) from/toward selfdeclared Roma classmates were summed. 
Control variables. Students were asked to classify themselves as 'Hungarian', 'Roma', 'both Hungarian and Roma', or members of 'another ethnicity'. Students who belonged to the Hungarian $(\mathrm{N}=317)$ or other ethnicity $(\mathrm{N}=4)$ categories were recorded as non-Roma. The Roma $(\mathrm{N}=105)$ and both Roma and Hungarian $(\mathrm{N}=90)$ categories were not changed. To control for students' ethnic selfidentification, the categories of self-declared ethnicity were included as dummy variables in the regression models, with non-Roma being the reference category. Data about students' ethnicity that were lacking were imputed using data from other waves 5 . I also controlled for students' gender.

\section{Analytical strategy}

The hypotheses were tested by random-intercept multilevel logistic regression analysis, on the one hand, and fractional regression analysis (Papke and Wooldridge, 1996; Ramalho et al., 2011) on the other. Fractional regression analysis was carried out using a robust cluster variance estimator, which reports standard errors that adjust for the clustering of students within classrooms. Fractional regression models are appropriate when the dependent variable is measured as a proportion with values between (or equal to) 0 and 1 (Papke and Wooldridge, 1996; Ramalho et al., 2011). One-part fractional regression models (Ramalho et al., 2011) with logit specification were estimated using Stata.

\section{RESULTS}

\section{Descriptive analysis}

Table 2 summarizes the descriptive statistics of the dependent and independent variables, and the associations between these variables and the self-declared ethnicity of students. On average, the mother's highest level of education is lower in the case of Roma students than in the case of non-Roma students and students with dual ethnic identification. Moreover, Roma students are more

5 Some changes in self-reports of ethnic identification occurred between the different waves (e.g., 11.9 per cent of students changed their self-reported ethnicity between the first and second waves, although over half of the changes occurred between the Roma and 'both Roma and Hungarian' categories), but ethnic self-identification reported in other waves is statistically the best predictor of the ethnic identification of students. 
often entitled to a regular child support allowance than their classmates. Roma students, moreover, send and receive more friendship nominations towards/ from their Roma classmates than non-Roma students.

Table 2. Descriptive statistics for variables among different ethnic groups (based on self-declared ethnicity of students)

\begin{tabular}{lcccc}
\hline & Non-Roma & Roma & $\begin{array}{c}\text { Roma and } \\
\text { Hungarian }\end{array}$ & Total \\
$\mathrm{N}$ & 321 & 105 & 90 & 559 \\
boy & $42.1 \%$ & $33.3 \%$ & $35.6 \%$ & $37.9 \%$ \\
classified as Roma by teacher & $5.0 \%$ & $81.0 \%$ & $63.3 \%$ & $29.7 \%$ \\
$\begin{array}{l}\text { Roma classification by peers } \\
\text { (standardized in-degree) mean (SD) }\end{array}$ & $0.03(0.07)$ & $0.36(0.17)$ & $0.27(0.18)$ & $0.14(0.19)$ \\
$\begin{array}{l}\text { number of Roma friends } \\
\text { (out-degree) mean (SD) }\end{array}$ & $1.1(1.8)$ & $3.8(3.9)$ & $2.7(2.9)$ & $1.8(2.7)$ \\
$\begin{array}{l}\text { number of Roma friends } \\
\text { (in-degree) mean (SD) }\end{array}$ & $1.3(1.5)$ & $3.6(2.6)$ & $2.9(2.3)$ & $2.0(2.1)$ \\
$\begin{array}{l}\text { entitled to regular child } \\
\text { support allowance }\end{array}$ & $30.8 \%$ & $77.1 \%$ & $67.8 \%$ & $46.3 \%$ \\
mother's highest educational & & & & \\
achievement & & & & \\
$\quad \begin{array}{l}\text { primary school or lower } \\
\text { vocational school }\end{array}$ & $21.1 \%$ & $78.8 \%$ & $65.5 \%$ & $40.3 \%$ \\
$\quad \begin{array}{l}\text { secondary education } \\
\text { tertiary education }\end{array}$ & $38.0 \%$ & $14.1 \%$ & $25.3 \%$ & $31.0 \%$ \\
\hline
\end{tabular}

Note: Kruskal-Wallis tests showed statistically significant differences between the three ethnic groups for all continuous variables $(p<0.001)$. Chi-squared tests showed statistically significant differences between the three ethnic groups for all categorical variables except for gender $(p<0.001)$.

The data show that although self-declared Roma students and students with both Roma and Hungarian ethnic identification are classified as Roma by a higher proportion of their classmates than non-Roma students, they are not consistently classified as Roma by their peers. Moreover, it more frequently occurs that selfdeclared Roma students are not classified as Roma by their peers than selfdeclared non-Roma students are classified as Roma by their classmates.

Similarly, the teachers' classification is more frequently consistent with nonRoma students' ethnic identification than with Roma students' self-declared ethnicity. Whereas only five per cent of self-declared non-Roma students were nominated by the headmaster as Roma, 19 per cent of self-declared Roma students were not nominated as Roma by their teacher. 


\section{Classification by teachers}

Table 3 presents the odds ratios obtained from the random-intercept multilevel logistic regression analysis which takes the hierarchical structure of our dataset (students nested in classrooms/teachers) into account. Results show that students with Roma and both Roma and Hungarian ethnic identification have far higher odds of being classified as Roma by their teacher than self-declared non-Roma students (OR: 66.02 and 32.36, respectively, $\mathrm{p}<0.001$ ). Gender does not play a significant role in being classified as Roma by the headmaster. Furthermore, additional analysis did not reveal any moderating effect of gender on the hypothesized relations between the variables.

Table 3. Random-intercept logistic regression model predicting Roma classification by headmaster

\begin{tabular}{lccc}
\hline Dependent variable & \multicolumn{3}{c}{ Odds ratios for being nominated as Roma } \\
Roma classification by the teacher & Est. & SE & $\mathrm{p}$ \\
intercept & 0.008 & 0.005 & 0.000 \\
self-declared ethnicity & & & \\
$\quad$ Roma & 66.018 & 36.149 & 0.000 \\
$\quad$ Roma and Hungarian & 32.361 & 15.232 & 0.000 \\
entitled to child support allowance & 7.208 & 2.914 & 0.000 \\
mother's educational achievement & & & \\
$\quad$ vocational school & 0.356 & 0.161 & 0.022 \\
$\quad$ secondary education & 0.579 & 0.334 & 0.343 \\
$\quad$ tertiary education & 0.655 & 0.556 & 0.618 \\
number of Roma friends (out-degree) & 1.412 & 0.173 & 0.005 \\
number of Roma friends (in-degree) & 1.078 & 0.089 & 0.364 \\
boy & 1.091 & 0.464 & 0.838 \\
\hline sd of residuals within groups & 1.270 & 0.392 & \\
intraclass correlation & 0.329 & 0.136 & \\
\hline N & & 499 \\
Wald chi2(9) & & 93.21 & \\
Log Likelihood & & -125.926 & \\
AIC & & 320.190 & \\
BIC & & \\
\hline
\end{tabular}


I expected that students living under better socio-economic circumstances would be less likely to be classified as Roma by their teachers than students living under worse socio-economic conditions (Hypothesis 1a). In line with this hypothesis, being entitled to a regular child support allowance significantly increases the odds of being classified as Roma by the headmaster (OR: 7.21, $\mathrm{p}<0.001)$. In terms of the different categories of mother's highest educational achievement, however, only vocational education has a significantly different effect than the reference category. Students whose mothers have completed vocational education have lower odds of being nominated as Roma by the headmaster than students whose mother only completed primary education (OR: 0.36, p<0.05).

I expected that students with more Roma friends in class were more likely to be classified as Roma by their teachers than students with fewer Roma friends (Hypothesis 2a). Results indicate that having one additional friendship nomination from a self-declared Roma classmate increases the odds of being classified as Roma by the headmaster by a factor of $1.41(\mathrm{p}<0.01)$. Students with more outgoing friendship nominations towards self-declared Roma classmates, however, are not significantly more likely to be classified as Roma by their teacher when incoming nominations are controlled for.

As a robustness check, I repeated the analysis with fixed-effects logistic regression models and random-intercept multilevel probit models. None of the alternative regression models generated different directions and significance for the parameter estimates. I also included the proportion of self-declared Roma students in the class and the type of class (vocational, technical, grammar) as class-level explanatory variables in the multilevel logit model, but they had no significant main effects on being classified as Roma, nor did they interact significantly with the individual-level independent variables.

\section{Classification by classmates}

Table 4 presents the odds ratios obtained from the fractional regression analysis. Results show that students with Roma (OR: 9.48, $\mathrm{p}<0.001)$ and both Roma and Hungarian (OR: 7.18, $\mathrm{p}<0.001$ ) ethnic identification were more likely to be classified as Roma by a higher proportion of their peers than non-Roma students. Gender does not have a statistically significant effect on being classified as Roma by peers. Moreover, additional analysis did not show any moderating effect of gender on the hypothesized relations between the variables. 
Table 4. Fractional regression model predicting Roma classification by peers

\begin{tabular}{lccc}
\hline Dependent variable: & \multicolumn{3}{c}{ Odds ratios for being nominated as Roma } \\
Roma classification by the peers & Est. & SE & p \\
\hline intercept & 0.031 & 0.008 & 0.000 \\
self-declared ethnicity & & & \\
$\quad$ Roma & 9.482 & 2.426 & 0.000 \\
$\quad$ Roma and Hungarian & 7.182 & 1.409 & 0.000 \\
entitled to child support allowance & 1.896 & 0.412 & 0.003 \\
mother's educational achievement & & & \\
$\quad$ vocational school & 0.753 & 0.068 & 0.002 \\
$\quad$ secondary education & 0.713 & 0.159 & 0.129 \\
$\quad$ tertiary education & 0.626 & 0.165 & 0.075 \\
number of Roma friends (out-degree) & 1.070 & 0.026 & 0.006 \\
number of Roma friends (in-degree) & 1.003 & 0.015 & 0.847 \\
boy & 0.904 & 0.206 & 0.657 \\
\hline $\mathrm{N}$ & & 499 & \\
Pseudo R2 & & 0.225 & \\
\hline
\end{tabular}

I expected that students living in better socio-economic circumstances would be less likely to be classified as Roma by their peers than students living in worse socio-economic conditions (Hypothesis $1 b$ ). Results are partially in line with this hypothesis. Students who are entitled to a regular child support allowance due to the low socio-economic status of their family are indeed more likely to have higher scores for Roma classification, even after controlling for ethnic self-identification. If a student is entitled to an allowance, then the odds of a classmate classifying him/her as Roma increase by a factor of $1.90(\mathrm{p}<0.01)$.

If the mother's highest educational attainment is vocational education, the odds of being classified as Roma decrease by a factor of $0.75(\mathrm{p}<0.01)$ compared to the reference category (primary school education). In contrast to the hypothesis, however, the mother's secondary and tertiary education does not have a statistically significant effect on the Roma classification score at the 0.05 significance level.

I expected that students with more Roma friends in the class would be more likely to be classified as Roma by their peers than students with fewer Roma friends (Hypothesis 2b). In line with this hypothesis, students who receive more friendship nominations from self-declared Roma students are more likely to 
be classified as Roma by a higher proportion of peers than students who are less popular among Roma peers. Having one additional incoming friendship nomination from a Roma classmate increases the odds of being classified as Roma by a factor of 1.07 ( $\mathrm{p}<0.01)$. Having outgoing friendship nominations towards self-declared Roma students, however, is not significantly associated with classification as Roma by peers if incoming friendship nominations are controlled for.

To see how robust the findings are if an alternative statistical model is used, I repeated the fractional regression analysis with the probit link function as well. The alternative model yielded the same direction and statistical significance for all parameter estimates except for the significant and marginally significant effects of mother's tertiary and secondary education $(\mathrm{p}=0.037$ for tertiary education, $\mathrm{p}=0.052$ for secondary education).

\section{CONCLUSIONS AND DISCUSSION}

In this study I examined ethnic classification processes among secondary school teachers and Roma and non-Roma Hungarian secondary school students. Based on previous research on Roma classification, I expected that students who lived under better socio-economic circumstances would be less likely to be classified as Roma by their teachers and peers than students living under worse socioeconomic conditions. I hypothesized that students with more Roma friends in the class would be more likely to be classified as Roma than students with fewer Roma friends. To test these hypotheses I first conducted cross-sectional multilevel logistic regression analysis to predict students' classification by headmasters. Then I estimated fractional regression models to analyze the associations between an aggregated measure of Roma classification by peers and the independent variables.

I found that self-declared Roma students were more likely to be classified as Roma by their teachers and peers than self-declared non-Roma students. Consistent with previous studies (Ladányi and Szelényi, 2006; Saperstein and Penner, 2012), however, I found considerable variations in the Roma classification scores of the students. Self-declared Roma students were nominated as Roma by on average 36 per cent of their classmates (ranging from a minimum of 0 to a maximum of 77 per cent). Students having dual (both Roma and Hungarian) ethnic identification were reported as Roma by an average 27 per cent of their classmates (ranging from a minimum of 0 to a maximum of 70 per cent). These data show that even if we take into account the fact that some students were 
missing during the period of data collection and some students did not answer this question (thus self-declared Roma students could not be classified as Roma by 100 per cent of their classmates), self-declared Roma students are frequently classified as non-Roma by their peers. Similarly, 19 per cent of the self-declared Roma students and 36.7 per cent of the students with dual ethnic identification were not nominated as Roma by their teacher. In sum, self-declared Roma students avoided being classified as Roma more frequently than self-declared non-Roma students were classified as Roma.

In line with the first hypothesis and previous studies (Csepeli and Simon, 2004; Ladányi and Szelényi, 2006), I found that students with a poorer socioeconomic background were more likely to be classified as Roma by teachers and peers than students living in better conditions. More specifically, students who were entitled to a regular child support allowance had higher odds of being classified as Roma than students not entitled to the allowance. The mother's highest level of education was used as another indicator of the socioeconomic status of students. From the different related categories, however, only vocational education had a significant negative effect. Students whose mothers had completed vocational education had significantly lower odds of being nominated as Roma by their peers and their headmaster than students whose mothers had only completed primary education. As it more frequently occurred that self-declared Roma students were not classified as Roma than self-declared non-Roma students were classified as Roma, these results actually suggest that students living in better conditions are more likely to avoid being nominated as Roma by their peers and teachers than students from poor families.

In line with the second hypothesis, students receiving more friendship nominations from self-declared Roma classmates were more likely to be classified as Roma than students receiving fewer nominations. These results actually suggest that self-declared Roma students who are not popular among their Roma peers are more likely to avoid being classified as Roma by teachers and classmates than Roma students who are popular in their ingroup. The finding that incoming friendship nominations are significantly related to being classified as Roma while (controlling for the incoming nominations) outgoing nominations are not, is in line with Boda's (2015) findings. After examining the co-evolution of dyadic friendship nominations and ethnic perceptions, the former author found that if student $\mathrm{A}$ is seen as popular (receives friendship nominations) among classmates student B perceives as Roma, then it is likely that student B will also perceive student A as Roma. In contrast, student A's friendship nominations towards classmates who are perceived as Roma by student B do not affect student B's perception of student A's ethnicity. 
These findings suggest that characteristics of the students' social and economic environment are strongly associated with ethnic classification. Since Roma students are more likely to receive lower grades than non-Roma students (Messing et al., 2010; Szalai, 2014), and further educational attainment is influenced by the grades students receive in their primary and secondary schools, students who can avoid being classified as Roma might have better educational careers than students classified as Roma. Unfortunately, data about students' grades were not available in the database so it could not be examined whether teachers are more likely to give lower grades to students they perceive as Roma than to students they perceive a non-Roma. Further research is needed to investigate these associations.

The major limitation of this study is that the student population in the sample does not represent the whole Roma student population in Hungary. Large regional differences exist in the socio-economic status, assimilation processes, and cultural characteristics of different Roma groups. In the north-east, the majority of the Roma belong to the Romungro Roma group, speak Hungarian as mother tongue, and have dual Roma and Hungarian ethnic identification. In the south-west, by contrast, more of the Roma population belong to the Boyash Roma group and speak a Roma language as mother tongue (Kemény et al., 2004). Similarly to the Roma living in the north-east, the vast majority of the Roma students in the sample reported belonging to the Romungro group and speaking only Hungarian with family members and friends. Classification processes might therefore show different patterns in other areas of Hungary than in the study sample.

A further limitation is that other factors that may also exert an influence on peer classification were not included in the analyses. Living in a Roma neighborhood, for instance, may increase the possibility of being classified as Roma by the classmates (Csepeli and Simon, 2004; Ladányi and Szelényi, 2006). In this dataset, data about the students' exact place of residence were not available. Future studies may take into account the effect of living in a segregated Roma neighborhood on being classified as Roma.

The third limitation is that qualitative and observational data about the wider social context of the participants and students' identity are not available. Differences in Roma students' ethnic identity might be perceived by their peers, which perceptions might also account for differences in ethnic classification. Furthermore, variations in school climate and the wider social context might influence ethnic identification and classification.

Moreover, the bidirectional causal link between having Roma friends and being classified as Roma was not examined in the analysis. I assumed that students who have more Roma friends are more likely to be classified as Roma 
than students who have fewer Roma friends. It is also possible, however, that students who are classified as Roma by their peers are more likely to select Roma friends or be selected as friends by Roma.

Future research should also focus on other age and ethnic groups. In this study, I analyzed a subsample of Roma and non-Roma first-year secondary school students in Hungary. The mechanisms of ethnic classification, however, might be different for various age groups such as children, pre-adolescents, adolescents, and adults. It should also be investigated how classification systems work in other countries, and in the case of other ethnic groups. Previous studies (Csepeli and Simon, 2004; Ladányi and Szelényi, 2006) suggest that ethnic perceptions might differ in different countries based on patterns of segregation and exclusion.

The major strength of this study is that I had the possibility to analyze a unique database containing information about the ethnic perceptions of teachers and students. It has been shown that ethnic classification varies depending on who does the classification, and that ethnic classification is not only associated with self-declared ethnicity but with other factors such as socio-economic status and the ethnicity of friends. These findings are important because being classified as a member of a low-status minority group might have far-reaching consequences on students' school grades, educational attainment, and later social position. It is therefore essential to understand the mechanisms underlying ethnic classification processes.

\section{REFERENCES}

Boda, Zsófia (2018), “Social Influence on Observed Race”, Sociological Science Vol. 5, pp. 29-57. https://doi.org/10.15195/v5.a3.

Boda, Zsófia (2015), Friendship Based on Race or Race Based on Friendship? The Co-Evolution of Friendships, Negative Ties and Ethnic Perceptions in Hungarian School Classes, Dissertation, Oxford, University of Oxford.

Boda, Zsófia - Bálint Néray (2015), "Inter-Ethnic Friendship and Negative Ties in Secondary School”, Social Networks Vol. 43, pp. 57-72. https://doi. org/10.1016/j.socnet.2015.03.004.

Burke, Peter J. (1991), "Identity Processes and Social Stress", American Sociological Review Vol. 56, No. 6, pp. 836-849. https://doi. org/10.2307/2096259.

Csepeli, György - Dávid Simon (2004), "Construction of Roma Identity in Eastern and Central Europe: Perception and Self-identification", Journal of 
Ethnic and Migration Studies Vol. 30, No 1, pp. 129-150. https://doi.org/10.10 80/1369183032000170204.

FRA. 2017. "Fundamental Rights Report, 2017.” European Union Agency for Fundamental Rights. http://fra.europa.eu/en/publication/2017/fundamentalrights-report-2017. (accessed: 30.01.2018)

Freeman, Jonathan B. - Andrew M. Penner - Aliya Saperstein - Matthias Scheutz - Nalini Ambady (2011), "Looking the Part: Social Status Cues Shape Race Perception", PLoS ONE Vol. 6, No 9, pp. 1-10. https://doi.org/10.1371/ journal.pone.0025107.

Harper, Casandra Elena (2016), "Pre-College and College Predictors of Longitudinal Changes in Multiracial College Students' Self-Reported Race", Race Ethnicity and Education Vol. 19, No 5, pp. 927-949. https://oi.org/10.1 080/13613324.2014.911161.

Hungarian Central Statistical Office (2013), www.ksh.hu/nepszamlalas/docs/ tablak/teruleti/00/00_1_1_6_1.xls. (accessed: 30.06.2017)

Kemény, István - Béla Janky (2006), "Roma Population of Hungary 1971-2003", in Kemény, István, ed., Roma of Hungary, East European Monographs, New York, Columbia University Press, pp. 70-225.

Kemény, István - Béla Janky - Gabriella Lengyel (2004), A Magyarországi Cigányság 1971-2003 [The Roma in Hungary 1971-2003], Budapest, Gondolat - MTA Etnikai-nemzeti Kisebbségkutató Intézet.

Kertesi, Gábor - Gábor Kézdi (2013), School Segregation, School Choice and Educational Policies in 100 Hungarian Towns, Roma Education Fund. http://www.romaeducationfund.hu/sites/default/files/publications/school segregationschool_choice_and_educational_policies_-_final_2013.pdf. (accessed: 30.06.2017)

Kertesi, Gábor - Gábor Kézdi (2012), "Ethnic Segregation Between Hungarian Schools: Long-Run Trends and Geographic Distribution", Hungarian Statistical Review Vol. 90, No 16, pp. 18-45.

Kertesi, Gábor - Gábor Kézdi (2011), "The Roma/Non-Roma Test Score Gap in Hungary", American Economic Review Vol. 101, No 3, pp. 519-525. https:// doi.org/10.1257/aer.101.3.519.

Kertesi, Gábor - Gábor Kézdi (2009), A Roma Fiatalok Általános Iskolai Eredményessége, Középiskolai Továbbtanulása És Középiskolai Sikeressége. Zárótanulmány [School Performance, Educational Success, and Secondary School Choices of Roma Youth. Final Study], MTA KTI, econ.core.hu/file/ download/jav/roma608.doc. (accessed: 30.06.2017)

Ladányi, János - Iván Szelényi (2006), Patterns of Exclusion: Constructing Gypsy Ethnicity and the Making of an Underclass in Transitional Societies of Europe, New York, Columbia University Press. 
McFarland, Daniel - Heili Pals (2005), "Motives and Contexts of Identity Change: A Case for Network Effects", Social Psychology Quarterly Vol. 68, No 4, pp. 289-315. https://doi.org/10.1177/019027250506800401.

Messing, Vera (2014), "Methodological Puzzles of Surveying Roma/ Gypsy Populations", Ethnicities Vol. 14, No. 6, pp. 811-829. https://doi. org/10.1177/1468796814542180.

Messing, Vera - Mária Neményi - Júlia Szalai (2010), Ethnic Differences in Education in Hungary: Survey Report, Budapest, Central European University, Center for Policy Studies. https://www.edumigrom.eu/sites/default/files/ field_attachment/page/node-5387/edumigromsurveyreporthungary_1.pdf. (accessed: 30.06.2017)

Munniksma, Anke - Maykel Verkuyten - Andreas Flache - Tobias H. Stark - René Veenstra (2015), "Friendships and Outgroup Attitudes among Ethnic Minority Youth: The Mediating Role of Ethnic and Host Society Identification", International Journal of Intercultural Relations Vol. 44, pp. 88-99. https://doi.org/10.1016/j.ijintrel.2014.12.002.

Papke, Leslie E - Jeffrey M. Wooldridge (1996), "Econometric Methods for Fractional Response Variables with an Application to 401(k) Plan Participation Rates", Journal of Applied Econometrics Vol. 11, No 6, pp. 619-632. https://doi.org/10.1002/(SICI)1099-1255(199611)11:6<619::AIDJAE418>3.0.CO;2-1.

Ramalho, Esmeralda A - Joaquim J.S. Ramalho - José M.R. Murteira (2011), "Alternative Estimating and Testing Empirical Strategies for Fractional Regression Models", Journal of Economic Surveys Vol. 25, No 1, pp. 19-68. https://doi.org/10.1111/j.1467-6419.2009.00602.x.

Saperstein, Aliya - Andrew M. Penner (2012), "Racial Fluidity and Inequality in the United States", American Journal of Sociology Vol. 118, No 3, pp. 676727. https://doi.org/10.1086/667722.

Schwartzman, Luisa Farah (2007), "Does Money Whiten? Intergenerational Changes in Racial Classification in Brazil", American Sociological Review Vol. 72, No 6, pp. 940-963. https://doi. org/10.1177/000312240707200605.

Sik, Endre - Bori Simonovits (2008), “Egyenlő Bánásmód És Diszkrimináció [Equal Treatment and Discrimination].” in Kolosi, Tamás - István György Tóth, eds, Társadalmi Riport, Budapest, TÁRKI, pp. 363-386.

Simonovits, Gábor - Gábor Kézdi (2014), "Poverty and the Formation of Roma Identity in Hungary: Evidence from a Representative Panel Survey of Adolescents", SSRN Scholarly Paper ID 2428607, Rochester, NY, Social Science Research Network, http://papers.ssrn.com/abstract=2428607. (accessed: 30.06.2017) 
Song, Miri (2001), “Comparing Minorities’ Ethnic Options: Do Asian Americans Possess 'More' Ethnic Options than African Americans?", Ethnicities Vol. 1, No 1, pp. 57-82. https://doi.org/10.1177/146879680100100110.

Stets, Jan E. - Peter J. Burke (2000), "Identity Theory and Social Identity Theory", Social Psychology Quarterly Vol. 63, No 3, pp. 224-237. https://doi. org/10.2307/2695870.

Stryker, Sheldon - Peter J. Burke (2000), "The Past, Present, and Future of an Identity Theory", Social Psychology Quarterly Vol. 63, No 4, pp. 284-297. https://doi.org/10.2307/2695840.

Szalai, Julia (2014), “The Emerging 'Ethnic Ceiling': Implications of Grading on Adolescents' Educational Advancement in Comparative Perspective." in Szalai, Júlia - Claire Schiff, eds, Migrant, Roma and Post-Colonial Youth in Education across Europe, London, Palgrave Macmillan UK, pp. 67-83. http://link.springer.com/10.1057/9781137308634_5.

Telles, Edward E. (2002), "Racial Ambiguity among the Brazilian Population”, Ethnic \& Racial Studies Vol. 25, No 3, pp. 415-441. https://doi. org/10.1080/01419870252932133.

Telles, Edward E. - Nelson Lim (1998), "Does It Matter Who Answers the Race Question? Racial Classification and Income Inequality in Brazil", Demography Vol. 35, No 4, pp. 465-474. https://doi.org/10.2307/3004014.

Telles, Edward E. - Tianna Paschel (2014), "Who Is Black, White, or Mixed Race? How Skin Color, Status, and Nation Shape Racial Classification in Latin America", American Journal of Sociology Vol. 120, No 3, pp. 864-907. https://doi.org/10.1086/679252.

Waters, Mary C. (1996), "Optional Ethnicities: For Whites Only?” in Pedraza, Sylvia - Ruben Rumbaut, eds, Origins and Destinies: Immigration, Race and Ethnicity in America, Belmont, CA, Wadsworth Press, 444-454. 